\title{
REACTION SHAPING OF THE UNMANNED AERIAL VEHICLE ON THE OPERATOR REMOTE STEERING SIGNALS
}

\begin{abstract}
Remote manual control of unmanned aerial vehicle is used more often during takeof and landing phases. Depends on UAV take-off mass and speed (total energy) the potential crash can be very dangerous for an airplane and environment. So, handling qualities of UAV is important from the user point of view. In many cases the dynamic properties of remote controlling UAV are not suitable for obtaining the desired properties of the handling qualities from operator's point of view. In this case, the control augmentation system (CAS) should be applied. The method of UAV handling qualities shaping is presented in this paper. The main idea of this method is that UAV reaction on the operator steering signals should be similar almost the same - as the reaction of the ,ideal" remote control aircraft. The model of following method was used for controller parameters calculations. The numerical example concerns the medium size UAV MP-02A Czajka applied as an aerial observer system.
\end{abstract}

Key words: unmanned aerial vehicle, controlling, augmentation system, autopilot

\section{Introduction}

Properties of the remote controlled UAV should ensure high quality of attitude stabilization and a transitory process of regulation [1-4]. This choice follows from designer's experience, and it can be named as an ,ideal model with good performance" [5]. In practice, the dynamic properties of the well-known aircraft which has good handling qualities characteristic from the operator point of view can be used as the ,ideal" model of UAV. The practical in application method of CAS control laws synthesis is described in this article, the model following method and computer simulation is used for solving this task.

This paper presents one aspect of the UAV projects, which have been worked out by Department of Avionics and Control Systems staff and students. The research team has some experience in this area. The first control system for UAV was designed in 1995 and next a few different projects were done [6-8].

\footnotetext{
2 Autor do korespondencji/corresponding author: Andrzej Tomczyk, Rzeszow University of Technology, 8 Powstańców Warszawy Avenue, 35-959 Rzeszow, tel. (17) 8651485, e-mail: atomczyk@prz.edu.pl
} 
Besides, the remote control task of UAV is similar to indirect flight control systems (Fly-by-Wire) designed by a Department team [9-11].

\section{Method of CAS control laws synthesis}

The acceptable dynamic properties and handling qualities of the remote controlled UAV are shape by the control law synthesis for desired properties of the modeled ,ideal” UAV obtaining. This task will be performed by application of the remote indirect flight control system (similar to fly-by-wire method), used to obtain the possibility of control system property modification. As a result, handling qualities of the real UAV will be shaped. The Control Augmentation System can be employed at the on-board control system of UAV or it can be used as a part of ground station software. The second solution makes possible to control of the UAV in the cases of critical failures of on-board control system. Receiver, simple amplifiers and actuators are necessary for UAV steering in this specific case, and handling qualities of UAV can be acceptable.

In this paper the second version of CAS configuration is taken into consideration. Algorithm to correct the properties of the control system is placed in the ground remote flight control station (Fig. 1). The task of synthesis consists in calculate the values of the coefficients matrix $\mathbf{K}_{\mathbf{A}}, \mathbf{K}_{\mathbf{M}}$ and $\mathbf{K}_{\mathbf{P}}$, to minimize the difference $(\boldsymbol{\Delta Y})$ of reaction between the UAV (state $\mathbf{Y}_{\mathbf{U}}$ ) and model output signals $\left(\mathbf{Y}_{\mathbf{M}}\right)$. In this way, the handling quality of UAV should be similar to ,ideal plane" from the operator point of view.

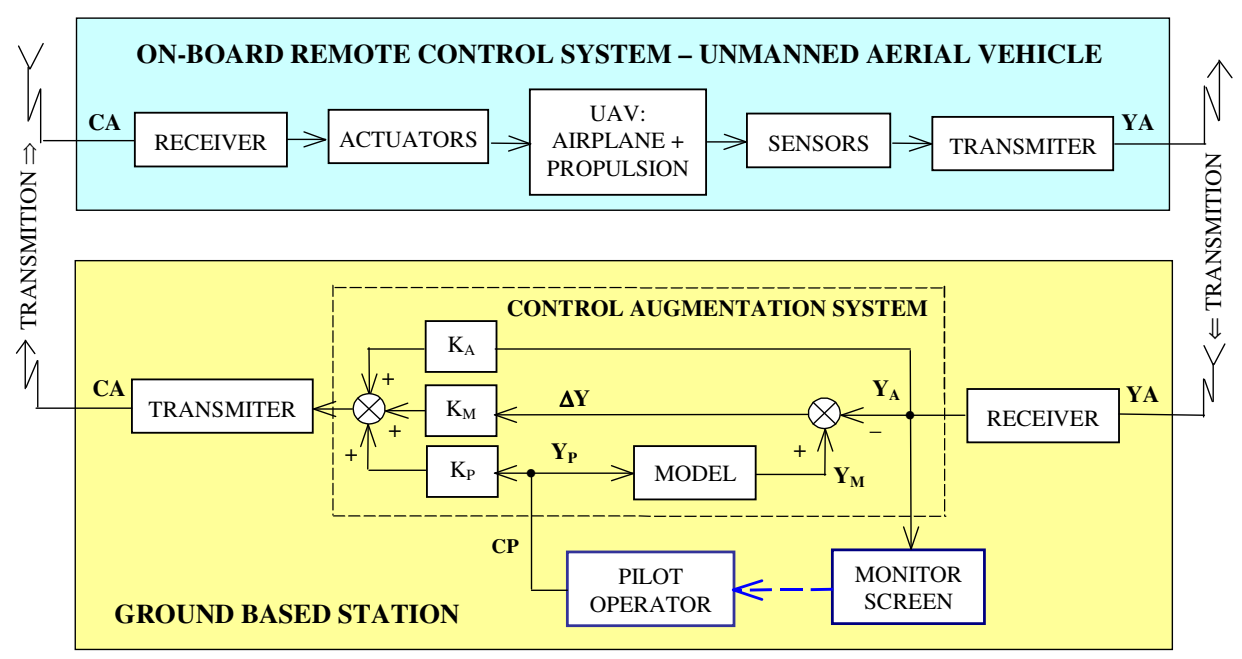

Fig. 1. Diagram of the model-following control augmentation system of UAV 
Model-following design technique is a well-known method for a control system synthesis, and it is very often used in design practice [12-14]. In this paper the original modified version of the direct model-following method, based on computer modeling and simulation is applied, which was described in the previous publications, for example [15]. The properties of the optimal controller were calculated applying the indirect (implicit) model of the following method. The model of the following method allows shaping properties of the flight control systems that satisfactorily approximate those of the desired model of controlled aircraft. In this way, the expected handling qualities from the operator point of view can be reached. Choosing the different models of desired aircraft we can test the new control laws, which are proposed for implementation in the UAV control systems. Establishing desired properties of operator-controlled, but automatically augmented UAV requires selecting proper control system structure. On the basis of to-date experiments, a direct model-following control structure, presented in figure 1 , has been chosen.

CAS algorithm matrices $\mathbf{K}=\left[\mathbf{K}_{\mathbf{A}}, \mathbf{K}_{\mathbf{M}}, \mathbf{K}_{\mathbf{P}}\right]^{\mathbf{T}}$ are calculated using the simulation method of model following control system synthesis and computer simulation. It means that the non-linear model of UAV and actuators can be used on the design calculations. The solution of the classical linear problem for the problem's simplified version may be used as a first approximation of the desired solution. Finally, the non-linear programming method with the inequality constraint functions will be used for the sub-optimal control laws choosing. The difference between the real aircraft and the desired model performance is defined as (see Fig. 2):

$$
\mathbf{E}(t)=\dot{\mathbf{Y}}_{\mathbf{M}}-\dot{\mathbf{Y}}_{\mathbf{A}}
$$

This kind of error between desired (modeled) and real output signals represents differences on dynamic reaction of modeled and real aircraft. In general, the steady-state performance of aircraft should be established in another way. The control function $\mathbf{U}(t)$ will be chosen to minimize the value of a quality control index

$$
J=\int_{0}^{\infty}\left(\mathbf{E}^{\mathrm{T}} \mathbf{Q E}+\mathbf{U}^{\mathrm{T}} \mathbf{R} \mathbf{U}\right) \mathrm{d} t
$$

For suboptimal simplified model following controller with feedback from observability of output signals (UAV and model output signals) and operator input signal, the control law is described by the following equation (see Fig. 2):

$$
\left.\begin{array}{l}
\mathbf{U}=\mathbf{K}_{\mathbf{P}} \mathbf{Y}_{\mathbf{P}}+\mathbf{K}_{\mathbf{M}} \mathbf{Y}_{\mathbf{M}}+\mathbf{K}_{\mathbf{A}} \mathbf{Y}_{\mathbf{A}} \quad \text { or } \\
\mathbf{U}=\mathbf{K Y}, \quad \mathbf{K}=\left[\mathbf{K}_{\mathbf{P}}, \mathbf{K}_{\mathbf{M}}, \mathbf{K}_{\mathbf{A}}\right], \quad \mathbf{Y}=\left[\mathbf{Y}_{\mathbf{P}}, \mathbf{Y}_{\mathbf{M}}, \mathbf{Y}_{\mathbf{A}}\right]^{\mathbf{T}}
\end{array}\right\}
$$




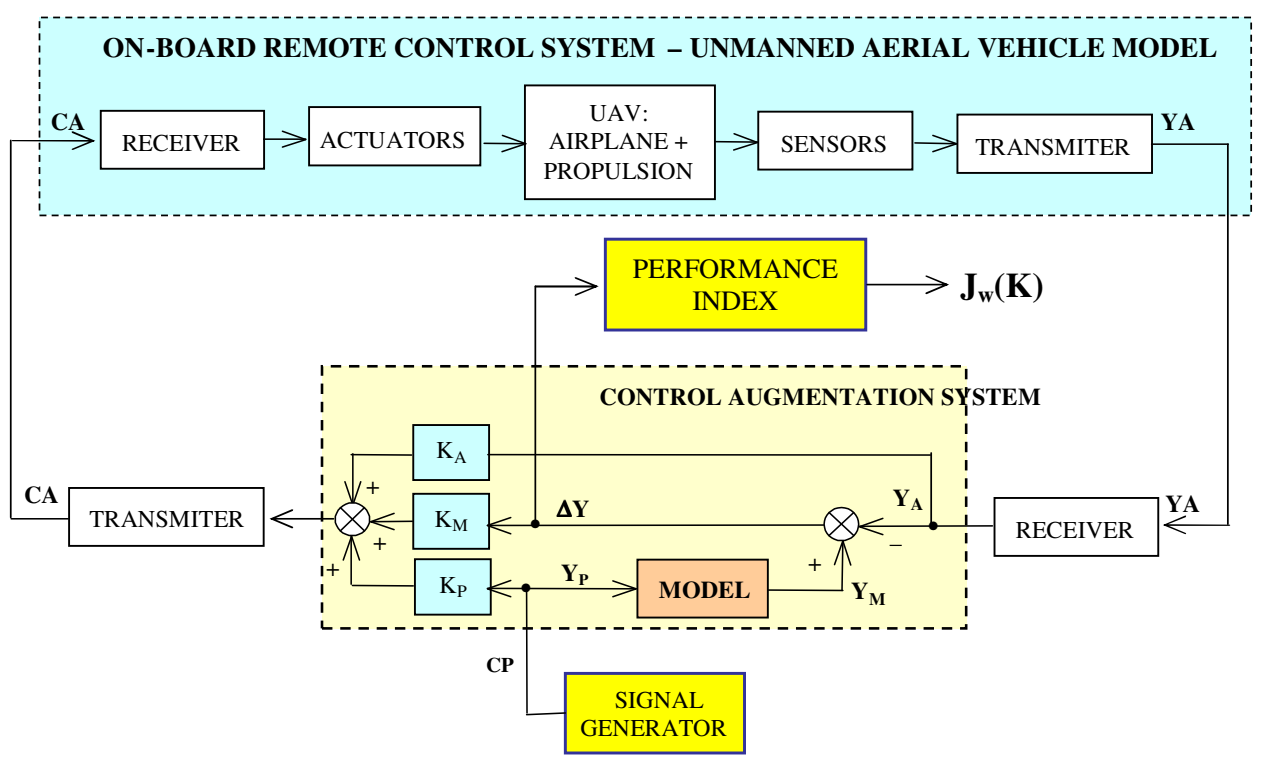

Fig. 2. Scheme of the model-following control augmentation system modeling

CAS controller matrices $\mathbf{K}_{\mathbf{i}}$ are calculated using the simulation method of model of following control system synthesis [15]. The method based on the computer simulation and employed the direct methods of the searching for the minimum of the performance index. The practical application becomes even more evident if we consider that in such a case a simplified linear model of the object's dynamics may be replaced with the full non-linear model. It is also possible to take into consideration many real-life restrictions, e.g. those concerning control signals. The solution of the classical linear problem for the problem's simplified version may be used as a first approximation of the desired solution. Finally, the non-linear programming method with the inequality constraint functions will be used for the sub-optimal control laws choosing [16]:

$$
\mathbf{J}(\mathbf{K})=\int_{0}^{\mathrm{T}_{\mathrm{f}}}\left(\mathbf{E}^{\mathrm{T}} \mathbf{Q E}+\mathbf{U}^{\mathrm{T}} \mathbf{R} \mathbf{U}\right) \mathrm{d} t
$$

where: $\mathbf{K} \in\left[\mathbf{K}^{\min }, \mathbf{K}^{\mathrm{max}}\right]$ - suboptimal value of the control matrix, lower and upper limitations of the gain matrix, respectively,

$T_{f}$ - finite period of integration, it is approximate equal period of the phugoid mode or the largest of the time constant of the aircraft motion.

In practice, because of the stability requirements, the modified version of performance index $\mathbf{J}_{\mathbf{W}}$ is used: 


$$
\mathbf{J}_{\mathbf{W}}(\mathbf{K})=\mathbf{J}(\mathbf{K})+d \sum_{j=1}^{p} g^{r_{j}} \quad r_{j}=\operatorname{real}\left(\lambda_{j}\right)
$$

where: $\lambda_{j}$ - eigenvalue of the linear approximation of the closed-loop control system,

$p$ - number of eigenvalues with $\operatorname{real}\left(\lambda_{i}\right) \geq 0$,

$d, g$ - parameters (weighting coefficients).

\section{Numerical examples}

At present a new version of the control system for medium size of the UAV (aerial observer) is designed at Rzeszow University of Technology. Figures $3 \div 6$ show the results of the control augmentation system design calculation for MP-02A UAV project (piston engine, take-off mass $m=470 \mathrm{~kg}$, IAS $=70-220$ $\mathrm{km} / \mathrm{h}$ ). The control augmentation system properties (described by matrix $\mathbf{K}$ ) are calculated for approach to landing configuration (flaps in $48^{\circ}$ position) with airspeed IAS $=24.9 \mathrm{~m} / \mathrm{s}$ and vertical speed VS $=2.4 \mathrm{~m} / \mathrm{s}$. As , ideal model” of UAV the mathematical ,ideal model with good performance" was applied [5]. It is evident that the reaction of the real MP-02A UAV for control stick deflection is similar to the reaction of the ,ideal UAV". The differences are not very important from the operator point of view because he is still active in the control loop and he can compensate the control errors (deviation from desired attitude). In other words, the dynamic properties of the controlled UAV are very similar to desired handling qualities.
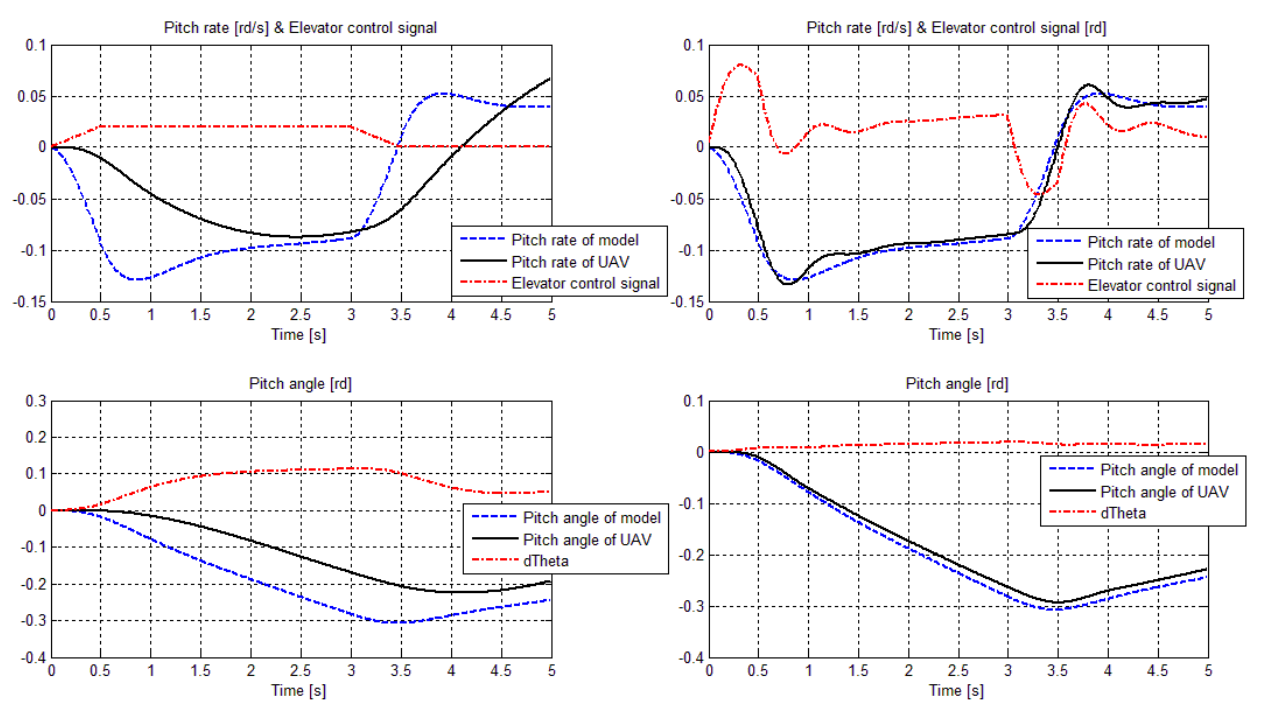

Fig. 3. Reaction of the augmented UAV on trapezoidal control signal - pitch channel 

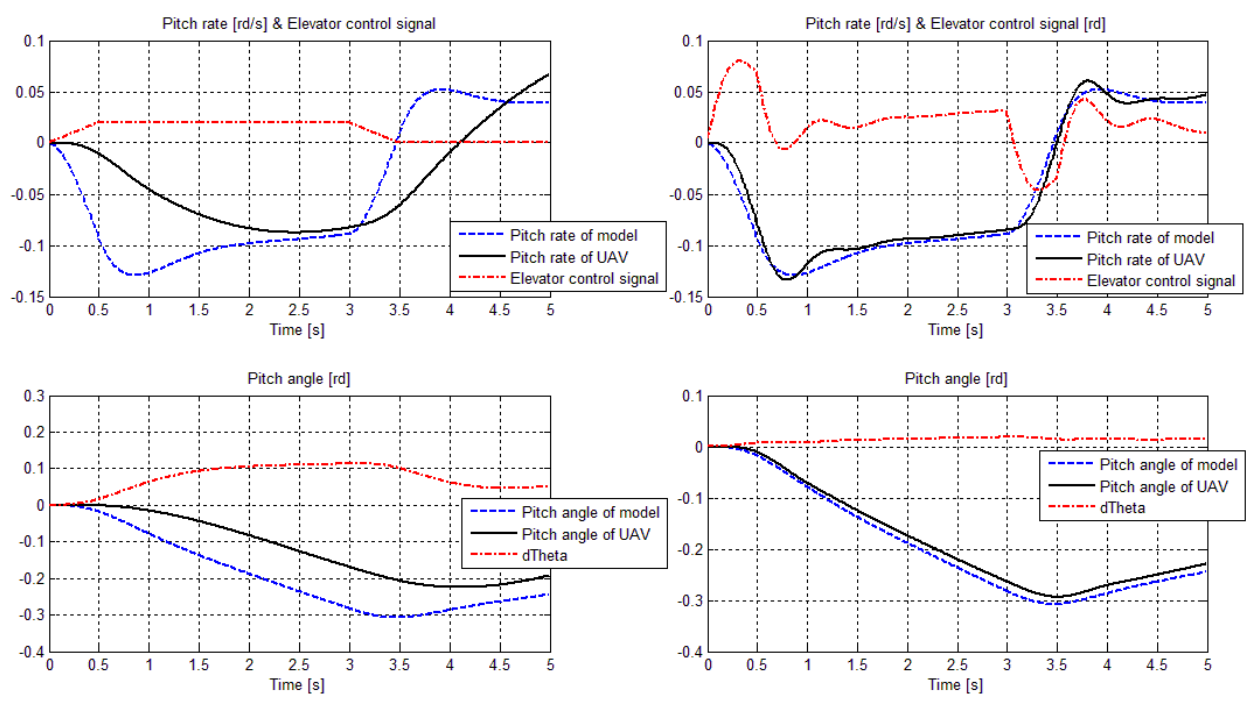

Fig. 4. Reaction of the augmented UAV on „3211” control signal - pitch channel
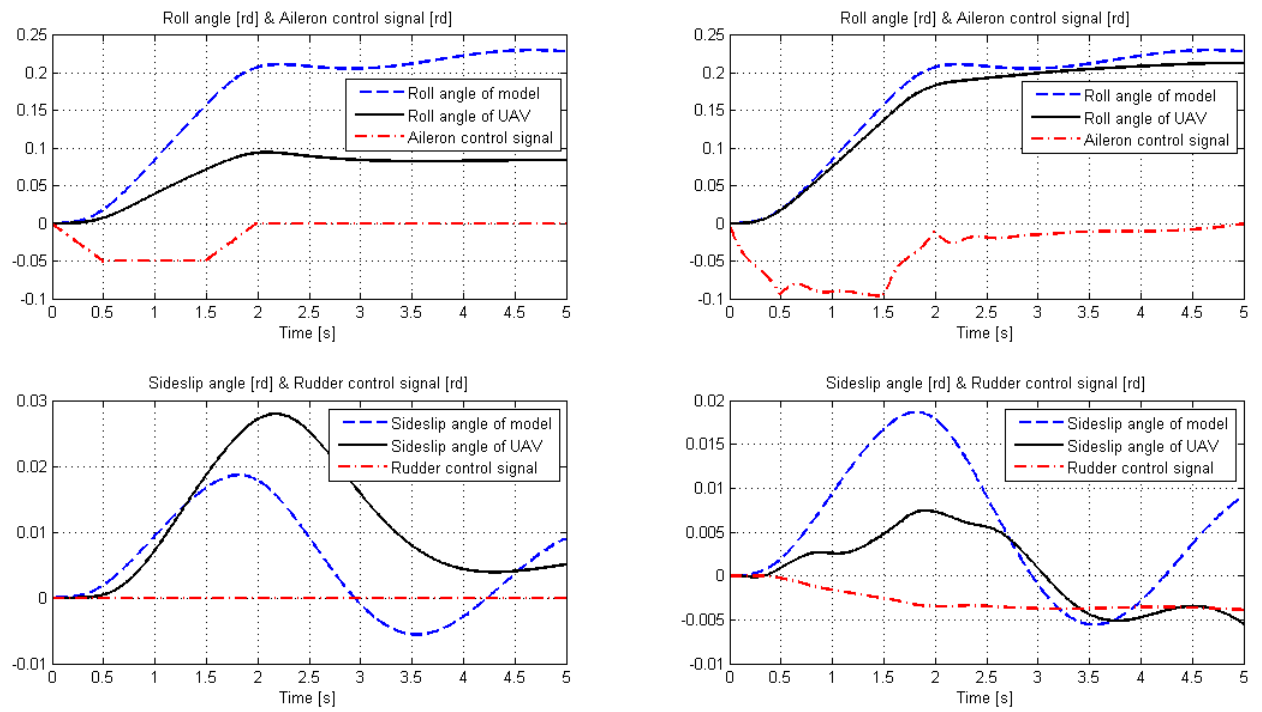

Fig. 5. Reaction of the augmented UAV on trapezoidal control signal - roll channel

Calculation was performed with Matlab-Simulink package. The operator's control signal has a trapezoidal shape in Figs. 3 and 5 and a typical shape used in flight testing named ,3211” (or „,2211”) for Figs. 4 and 6. Plots show the reaction of UAV and modeled ,ideal aircraft" for landing configuration on the same operator's control signal. If the control system is switched on, the same operator's action causes different control signal generation, which activates actuator 

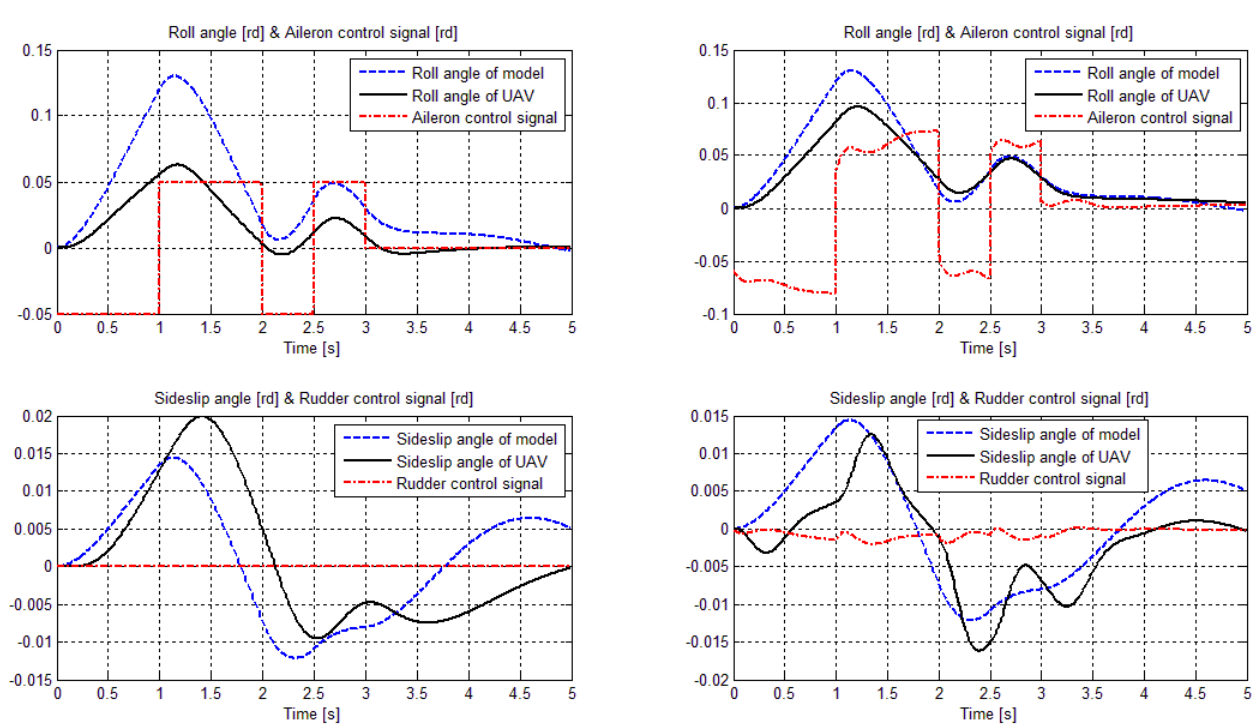

Fig. 6. Reaction of the augmented UAV on „2211” control signal - roll channel

of elevator (line CA, pictures on the right). The delay caused by actuator inertia is visible. Pitch rates and pitch angles of the model and the real UAV are very similar. In this way, from a pilot's point of view the augmented UAV reaction on control stick displacement is similar to ,ideal" aircraft reaction on the same pilot action. It is possible to say that handling properties concern attitude orientation of the UAV is similar to modeled ,ideal" aircraft.

The dynamic properties of the typical UAV are similar to handling qualities of classical aeroplanes. From the remote-piloted operator point of view the properties of the UAV defined as ,rate control, attitude hold” are more useful [11, 17]. It means that control stick displacement causes change of UAV orientation (pitch rate or roll rate is generated) and new pitch and/or roll angles are stabilized after moving of the control stick to neutral position. This kind of ,ideal UAV" is used in the analyzed examples. The next step in the handling qualities improving can be applied the active command stick. Some experience in this area is stored in the Department of Avionics and Control Systems [18].

\section{Summary}

Results of the modeling and calculation show that the reaction in longitudinal and lateral motion of the UAV for operator's control stick displacement should be similar to the reaction of the modeled ,ideal UAV". It is possible to say that handling properties concern attitude orientation of the real UAV is similar to desired ones. The modeling and simulation technique is the good way for synthesis and evaluate of the handling qualities during UAV take-off and lan- 
ding. The presented method of the control augmentation system properties calculations and numerical examples concern the remote steering of the unmanned aerial vehicles. Results of the calculation show that the reaction in longitudinal and lateral motion of the UAV for operator's control stick displacement should be similar to the reaction of the modeled ,ideal UAV". It is possible to say that handling properties concern attitude orientation of the real UAV is similar to desired ones. It means that it is possible to modify dynamic characteristics of the UAV in this way. From on-ground operator point of view the unmanned aerial vehicle dynamic properties can be acceptable. The safety flight, especially during take-off and landing phases, is possibility of success. The second reason for control augmentation system applying is standardization of the handling qualities of different unmanned aerial vehicles.

\section{References}

[1] Austin R.: Unmanned aircraft systems: UAVS Design. Development and Deployment, AIAA Education Series, 2010.

[2] Bernhard R.K., Shappee E., Marshall D.M.: Introduction to unmanned aircraft systems. CRC Press, 2011.

[3] Hamilton J.: UAVs: Unmanned aerial vehicles. ABDO, 2012.

[4] Newcome L.R.: Unmanned aviation. Library of Flight, 2004.

[5] Stevens B.L., Lewis F.L.: Aircraft control and simulation. J. Wiley \& Sons, 2004.

[6] Gruszecki J. (ed.): Unmanned aerial vehicles. Control and navigation systems. Oficyna Wydawnicza Politechniki Rzeszowskiej, Rzeszów 2002 (in Polish).

[7] Tomczyk A., Gruszecki J.: Preliminary project of the autonomous landing system for unmanned aircraft. AIAA-SAE Paper 99-01-5524, World Aviation Congress \& Exposition, San Francisco 1999.

[8] Tomczyk A.: In-flight tests of navigation and control system of unmanned aerial vehicle. Aircraft Eng. Aerospace Technol.: An Inter. J., 75 (2003), 581-587.

[9] Tomczyk A.: Experimental fly-by-wire control system for general aviation aircraft. AIAA Paper No. 2003-5776, 2003.

[10] Tomczyk A.: Facilitated airplane - project and preliminary in-flight experiments. Aerospace Sci. Technol., 8 (2004), 469-477.

[11] Tomczyk A., Rzucidło P.: Indirect flight control systems for general aviation aircraft. Oficyna Wydawnicza Politechniki Rzeszowskiej, Rzeszów 2011 (in Polish).

[12] Astrom K.J., Wittenmark B.: Adaptive control. Addison-Wesley Publishing Company, 1989.

[13] Huang C., Tylock J.: Comparison of modern model-following aircraft control techniques. AIAA-93-3843, AIAA Guidance, Navigation and Control Conference, Monterey 1993, pp. 1274-1284.

[14] Kreindler E., Rothschild D.: Model-following in linear-quadratic optimization. AIAA Journal, 14 (1976), 835-842.

[15] Tomczyk A.: Digital flight control systems. Oficyna Wydawnicza Politechniki Rzeszowskiej, Rzeszów 1999 (in Polish). 
[16] Gill P.E., Murray W., Wright H.M:. Practical optimization. Academic Press, 1981.

[17] Lambregts A.A.: Fundamentals of FBW augmented manual control. SAE Paper, SAE-2005-01-3419, 2005.

[18] Pieniążek J.: Active command interfaces in fly-by-wire control. Systems Science, 34 (2008), 68-75.

\section{Acknowledgment}

This scientific work has been partly financed from the Polish scientific funds for years 2010-2012 as a development project No. OR00011611.

\section{KSZTAŁTOWANIE REAKCJI BEZZAŁOGOWEGO STATKU PO- WIETRZNEGO NA SYGNAŁY STERUJĄCE OPERATORA}

\section{Streszczenie}

Bezzałogowy statek powietrzny może być sterowany w różny sposób, a jednym z nich jest zdalne sterowanie przez operatora, np. podczas startu i lądowania lub lotu obserwacyjnego, w którym jest wymagane aktywne modyfikowanie trajektorii lotu. Nie zawsze bezzałogowy statek powietrzny posiada właściwości dynamiczne akceptowalne lub pożądane z punktu widzenia operatora. W referacie jest rozważany sposób kształtowania reakcji samolotu na sygnały sterujące operatora (wychylenia organów sterowania), tak aby były zgodne z oczekiwanymi (modelowymi) właściwościami pilotażowymi. W tym celu należy dokonać syntezy właściwości układu wspomagającego sterowanie odległościowe. Algorytmy wspomagające operatora mogą stanowić fragment oprogramowania sterującego zaimplementowanego $\mathrm{w}$ autopilocie bezpilotowego statku powietrznego lub mogą być zastosowane w module sterującym w stacji naziemnej. W tym drugim przypadku istnieje możliwość zastosowania bardziej złożonych algorytmów oraz łatwego dostosowania właściwości pilotażowych samolotu do oczekiwań operatora zależnie od jego preferencji lub stanu lotu. Do syntezy właściwości układu wspomagającego sterowanie ręczne zastosowano modyfikowaną metodę sterowania według modelu, a przykładowe obliczenia dotyczą samolotu MP-02A Czajka, będącego nośnikiem systemu obserwacyjnego LOT.

Słowa kluczowe: bezzałogowy statek powietrzny, sterowanie, algorytmy wspomagające, autopilot

DOI:10.7862/rm.2013.49

Otrzymano/received: 15.09.2013 r.

Zaakceptowano/accepted: 22.11.2013 r. 